\title{
Genetic variability of the symbiotic dinoflagellates from the wide ranging coral species Seriatopora hystrix and Acropora longicyathus in the Indo-West Pacific
}

\author{
William K. W. Loh ${ }^{1,2, *}$, Toha Loi $^{2}$, Dee Carter ${ }^{2}$, Ove Hoegh-Guldberg ${ }^{1}$ \\ ${ }^{1}$ Centre for Marine Studies, University of Queensland, St Lucia Qld 4069, Australia \\ ${ }^{2}$ The Department of Microbiology, The University of Sydney, Sydney NSW 2006, Australia
}

\begin{abstract}
The scleractinian coral species, Seriatopora hystrix and Acropora longicyathus, are widely distributed throughout the latitudinal range of the tropical west Pacific. These 2 coral species live in a mutually beneficial relation with symbiotic dinoflagellates (zooxanthellae), which are passed to their progeny by vertical transmission (zooxanthellate eggs or larvae) and horizontal transmission (eggs or larvae that acquire symbionts from the environment), respectively. For $S$. hystrix, vertical transmission might create biogeographically isolated and genetically differentiated symbiont populations because the extent of its larval migration is known to be limited. On the other hand, horizontal transmission in corals such as A. longicyathus may result in genetically connected symbiont populations, especially if its zooxanthellae taxa are widely distributed. To examine these hypotheses, symbionts were collected from colonies of $S$. hystrix and A. longicyathus living in the Great Barrier Reef (Australia), South China Sea (Malaysia) and East China Sea (Ryukyus Archipelago, Japan), and were examined using restriction fragment length polymorphism and sequence analysis of large and small subunit rRNA genes. Phylogenetic analysis assigned the symbionts to 1 of 3 taxonomically distinct groups, known as clades. Symbionts from Australian and Japanese S. hystrix were placed in Clade C, and Malaysian S. hystrix symbionts in the newly described Clade D. Seven of 11 Australian and all Japanese and Malaysian colonies of $A$. longicyathus had symbiotic dinoflagellates that also grouped with Clade C, but symbionts from the remaining Australian colonies of A. longicyathus grouped with Clade A. Analysis of molecular variance of Clade C symbionts found significant genetic variation in 1 or more geographic groups $(69.8 \%)$ and to a lesser extent among populations within geographic regions $(13.6 \%)$. All populations of Clade C symbionts from $S$. hystrix were genetically differentiated according to geographic region. Although Clade C symbionts of A. longicyathus from Japan resolved into a distinct geographic group, those from Australia and Malaysia did not and were genetically connected. We propose that these patterns of genetic connectivity correlate with differences in the dispersal range of the coral or symbiont propagules and are associated with their respective modes of symbiont transmission.
\end{abstract}

KEY WORDS: Seriatopora hystrix · Acropora longicyathus · Symbiotic dinoflagellates · Geographic population variation

\section{INTRODUCTION}

All hermatypic (reef-building) corals harbor endosymbiotic dinoflagellates (zooxanthellae) in their tis-

*E-mail: w.loh@microbio.usyd.edu.au sues that form a mutualistic symbiosis in which the host benefits from the transfer of photosynthetic products and the symbiotic dinoflagellate benefits from the provision of otherwise rare inorganic nutrients (Trench 1979). Other advantages are also thought to accrue from the association of the coral host and dinoflagel- 
late, such as the enhancement of calcification through the removal of carbon dioxide or phosphate or both (Goreau \& Goreau 1959, Simkiss 1964a,b).

Symbiotic dinoflagellates of cnidaria are mostly classified under the genus Symbiodinium (Dinophyceae), although at least 1 species has been placed in genus Gymnodinium (Trench \& Thinh 1995, Wilcox 1998). They are a taxonomically diverse group (Schoenberg \& Trench 1980a,b,c, Blank \& Trench 1985, Trench \& Blank 1987, Trench \& Thinh 1995) and generally host specific (Rowan \& Powers 1991b). Among those that have been taxonomically defined are $S$. kawaguti (Trench \& Blank 1987) and S. meandrinae (Trench 1997, isolated by Trench) from the scleractinian corals Montipora verrucosa and Meandrina meandrites, respectively; S. goreauii (Trench \& Blank 1987), S. pulchorum, S. bermudense, S. cariborum and S. californium (Trench 1997, isolated by Trench) from the actinarians Ragactis lucida, Aiptasia pulchella, A. tagetes, Condylactis gigantea and Anthopleura elegantissima, respectively; $S$. corculorum that was isolated by Trench from the bivalve Corculum cardissa; $S$. pilosum (Trench \& Blank 1987) from the zoanthid Zoanthus sociatus; and S. microadriaticum (Freudenthal emend. Trench) and Gymnodinium linucheae (Trench \& Thinh 1995) from the medussae Cassiopeia xamachana and Linuche unguilata, respectively (Trench \& Blank 1987, Trench \& Thinh 1995, Trench 1997).

However, it must be pointed out that these symbionts have been cultured, and cultivation-dependent methods may not accurately represent the in situ diversity that may exist. This is because culturing might be enhancing or inhibiting the growth of particular microorganisms (Ward et al. 1990, Amann et al. 1995). In addition, Wilcox (1998) showed that morphological similarities do not always delineate symbiotic dinoflagellates into evolutionarily cohesive groups.

Analysis of large and small subunit ribosomal genes of several of these symbiotic dinoflagellate species has revealed that the symbionts belong to 1 of 3 diverse genotypic clades that have been nominally denoted clades 'A', 'B' and 'C' (Rowan \& Powers 1991a,b). Although evidence suggests that all 3 clades are distributed evenly among Caribbean coral species, Clade C appears to be predominant among the relatively few Pacific coral species that have been surveyed (Baker \& Rowan 1997, Loh et al. 1998). More recently, a fourth clade, ' $\mathrm{D}$ ', of dinoflagellates has been identified (Baker 1999).

Many cnidarians, including some corals, transfer their symbionts maternally (vertical transmission) into larvae or into planulae that are initially brooded (Richmond 1981, Benayahu \& Schleyer 1998, Shlesinger et al. 1998, Sier \& Olive 1998, Titlyanov et al. 1998). Symbionts may also be transferred to pre-released eggs in other coral species (Szmant et al. 1980, Arai et al. 1993, Schwarz et al. 1999). Many other coral species release planulae or eggs that do not contain symbiotic dinoflagellates (Kojis 1986, Harrison \& Wallace 1990). In this case, symbioses are initiated by capture of dinoflagellates from the water column or other environmental source (horizontal transmission). Conceivably, these transmission strategies may influence the diversity of symbionts that are established within coral colonies.

Many coral species occur across a wide range of tropical Indo-Pacific locations. Under these situations, the host and associated symbiont experience widely varying environmental conditions. On high latitude reef systems, corals may experience cold-water temperatures and very low light levels in the winter, and greatly contrasting higher water temperatures and light levels in the summer. The symbiotic dinoflagellates of reef-building corals are sensitive to changes in light and temperature (Jones et al. 1998, Hoegh-Guldberg \& Jones 1999). Consequently, the question as to whether the identity of the symbiotic dinoflagellate remains the same in its coral host at different parts of their often wide-ranging distribution is of great interest. This is complicated further by the symbiont acquisition strategies of corals that rely on vertical or horizontal transmission. We have addressed this question by investigating the molecular diversity of symbiotic dinoflagellates from 2 widely distributed coral species, Seriatopora hystrix and Acropora longicyathus, at 3 disparate locations in the Indo-Pacific. S. hystrix is a brooding species (Ayre 1994) and transfers its symbionts vertically to its planulae from the maternal phase (Atoda 1951, D. Ayre, University of Wollongong, pers. comm.). A. longicyathus is a broadcasting species (Wallace 1985, Shlesinger et al. 1998) and eggs that are released by adult colonies do not have symbiotic dinoflagellates (Harrison \& Wallace 1990, S. Ward, University of Queensland, pers. comm.). The locations chosen were the Great Barrier Reef, Australia in the south Pacific, and South China Sea, Malaysia and East China Sea, Japan in the northern Pacific.

\section{MATERIALS AND METHODS}

Collection and identification of coral samples. The 2 coral species used for this study were Seriatopora hystrix Dana (Scleractinia: Pocilloporidae) and Acropora longicyathus Edwards and Haime (Scleractinia: Acroporidae). Corals were sampled on snorkel at a depth of 1 to $6 \mathrm{~m}$. The sites were coral reefs off the following islands: One Tree Island $\left(23^{\circ} 152^{\prime} \mathrm{S}, 152^{\circ} 06^{\prime} \mathrm{E}\right)$, southern Great Barrier Reef, Australia; Pulau Redang and Pulau Gaya $\left(6^{\circ} \mathrm{N}, 103^{\circ} \mathrm{E}, 6^{\circ} \mathrm{N}, 116^{\circ} \mathrm{E}\right.$, respectively, South China Sea), Malaysia; and Sesokojima 
and Akajima $\left(27^{\circ} \mathrm{N}, 128^{\circ} \mathrm{E}, 26^{\circ} \mathrm{N}, 127^{\circ} \mathrm{E}\right.$, respectively, East China Sea), Japan. For each species, colonies that were at least $10 \mathrm{~m}$ apart were chosen for sampling. The samples were identified using monographs (Veron \& Pichon 1976, Veron \& Wallace 1984) and confirmed by reference to the collection at the Queensland Tropical Museum, Townsville, Australia. Colony designations and their sampling locations are summarized in Table 1.

Extraction of DNA. Live fragments of coral colonies (approximately $4 \mathrm{~cm}^{2}$ ) were collected, placed in sterile plastic bags and blown with directed jets of high-pressure air to remove tissues from the skeletons. The ensuing tissue slurry was collected from the bottom of the bag and an approximately equal volume of DNA preservative (20\% DMSO in 0.25 M EDTA, pH 8.0 and saturated with $\mathrm{NaCl}_{i}$ Seutin et al. 1991) was added. The samples were stored and transported at temperatures that ranged from $0^{\circ} \mathrm{C}$ to ambient, or processed immediately.

Tissue slurries were incubated in $1 \%$ sodium dodecyl-sulfate (Boehringer Mannheim, Mannheim, Germany) at $65^{\circ} \mathrm{C}$ for $1 \mathrm{~h}$. This was followed by digestion with Proteinase K (Boehringer Manheim), which was added to a final concentration $0.5 \mathrm{mg} \mathrm{ml}^{-1}$ and incubated at $37^{\circ} \mathrm{C}$ for 8 to $12 \mathrm{~h}$. An equal volume of phenol was added to the digested slurry, which was mixed and centrifuged $\left(10000 \times g, 10 \mathrm{~min}, 21^{\circ} \mathrm{C}\right)$. The aqueous phase was removed and subjected to a second extraction using phenol-chloroform (25:24) and a third using chloroform-isoamyl alcohol (25:1). DNA was precipitated by the addition of $1 / 10$ volume of $3 \mathrm{M}$ sodium acetate ( $\mathrm{pH} 5.2)$ and an equal volume of cold isopropanol $\left(0^{\circ} \mathrm{C}\right)$. The precipitate was washed with $70 \%$ ethanol, dried, dissolved in $50 \mu \mathrm{l}$ of sterile Milli-Q water and stored at $-70^{\circ} \mathrm{C}$.

PCR amplification and restriction fragment length polymorphism analysis. The $18 \mathrm{~S}$ rRNA gene was amplified from symbiotic dinoflagellates using the primer set designed by Rowan \& Powers (1991a). These were an equimolar mixture of 2 forward primers, 5'-GCA GTT ATA ATT TAT TTG ATG GTC ACT GCT AC-3' and 5'-GCA GTT ATA ATT TAT TTG ATG GTT GCT GCT AC-3', with the reverse primer 5'-AGC ACT GCG TCA GTC CGA ATA ATT CAC CGG-3'.

The variable domains D1 and D2 of the 28S rRNA gene were amplified from coral and their symbiotic dinoflagellates using a primer set designed by Zardoya et al. (1995). These were forward 5'-CCC GCT GAA TTT AAG CAT ATA AGT AAG CGG-3' and reverse 5'-
GTT AGA CTC CTT GGT CCG TGT TTC AAG A-3' (position 26 and 741, respectively, in the 28S rDNA sequence of the free-living dinoflagellate Prorocentrum micans, Genbank accession no. X16108). Primers specific to symbiotic dinoflagellates were also designed based on subsequent sequencing and comparison of the D1 and D2 region of coral and symbiotic dinoflagellate 28S rRNA genes (see below for size differentiation of coral and symbiont amplicon). These primers were forward $5^{\prime}$-CCT CAG TAA TGG CGA ATG AAC A-3' and reverse 5'-CCT TGG TCC GTG TTT CAA GA-3'.

All PCR reactions contained $0.4 \mu \mathrm{g}$ of template DNA, $10 \mu \mathrm{l}$ of $10 \times$ PCR buffer (1 M Tris- $\mathrm{HCl}[\mathrm{pH}$ 8.3], $0.5 \mathrm{M}$ $\mathrm{KCl}, 15 \mathrm{mM} \mathrm{MgCl} 2), 1 \mu \mathrm{l}$ of $10 \mathrm{mM}$ total deoxyribonucleoside triphosphates, $40 \mu \mathrm{g}$ DNAase-free bovine serum albumin (Amersham Biosciences, Uppsala, Sweden), 20 pmol of each primer and 5 units of Taq polymerase (Ampli-Taq, Perkin Elmer, Wellesley, MA) in a total volume of $100 \mu \mathrm{l}$. Amplifications were performed using a DNA thermal cycler (Cetus 2400, Perkin Elmer) with the following conditions: $94^{\circ} \mathrm{C}$ for $1 \mathrm{~min}, 55^{\circ} \mathrm{C}$ (18S rRNA gene primers) or $65^{\circ} \mathrm{C}(28 \mathrm{~S}$ rRNA gene primers) for $2 \mathrm{~min}$, and $72^{\circ} \mathrm{C}$ for $3 \mathrm{~min}$ (35 cycles).

The amplicons were analyzed by electrophoresis in $2 \%$ agarose gels $\left(10 \mathrm{~V} \mathrm{~cm}^{-1} ; 40 \mathrm{~mA}\right)$, stained with ethidium bromide and visualized with UV transillumination. Where they were co-ampified, coral and dinoflagellate 28S rDNA amplicons were identified in the gel by their sizes of approximately 885 and $650 \mathrm{bp}$, respectively. A gel plug containing each separate amplicon was removed by plunging a truncated yellow pipette tip into the amplified band, which was then expunged into $50 \mu \mathrm{l}$ of sterile Milli-Q water and melted at $95^{\circ} \mathrm{C}$. Reamplification PCR reactions were set up as before except for the use of $1 \mu \mathrm{l}$ melted gel solution as the template DNA.

Table 1. Coral host species, symbiont/colony codes used and sampling locations

\begin{tabular}{|lll|}
\hline Sceriatopora hystrix & Acropora longicyathus & Location \\
\hline Sh1A, Sh2A, Sh3A, & Al1A, Al2A, Al3A, Al5A, & Great Barrier Reef, \\
Sh4A, Sh5A, Sh6A, & Al6A, Al13A, Al25A, & Australia \\
Sh7A, Sh8A, Sh9A, & Al26A, Al43A, Al45A, & \\
Sh10A & Al53A & \\
Sh1M, Sh2M, Sh3M, & Al1M, Al2M, Al3M, Al4M, & South China Sea, \\
Sh4M, Sh5M, Sh6M, & Al5M, Al6M, Al7M, Al8M, & Malaysia \\
Sh7M, Sh8M, & Al9M, Al10M, Al11M, & \\
Sh9M & Al12M & East China Sea, \\
Sh1J, Sh2J, Sh3J, & Al1J, Al2J, Al3J, & Japan \\
Sh4J, Sh5J, Sh6J, & Al4J, Al5J, Al6J, & \\
Sh7J, Sh8J, Sh9J, & Al7J, Al8J, Al9J, & \\
Sh10J, Sh11J, & Al10J, Al11J & \\
Sh12J & & \\
\hline
\end{tabular}


Restriction fragment length polymorphism (RFLP) analysis of the $18 \mathrm{~S}$ or $28 \mathrm{~S}$ rDNA amplicons was done by restriction digestion with Taq 1 restriction enzyme (Progen Industries, Darra, QLD, Australia) for $3 \mathrm{~h}$ at $65^{\circ} \mathrm{C}$. The digested amplicons were then analyzed by electrophoresis in $2 \%$ agarose gels $\left(10 \mathrm{~V} \mathrm{~cm}^{-1} ; 40 \mathrm{~mA}\right)$, and visualization by ethidium bromide staining and UV transillumination.

DNA sequencing. PCR amplifications (or reamplifications) that produced a single amplicon were purified for direct sequencing by polyethylene glycol precipitation (Rosenthal et al. 1993). The sequence was determined from 1 or both ends of the rRNA gene using dyeterminators and a 373A DNA automated sequencer (Perkin-Elmer). Sequencing was done at the Sydney University and Prince Alfred Molecular Analysis Centre, and the Australian Genome Research Facility at the University of Queensland.

DNA sequences of symbiont genotypes derived in this study are available in GenBank Accession numbers for symbionts Al2A, Al3A, Al5A, Al6A, Al13A, Al25A, Al26A, Al45A, Al53A, Al1M, Al3M, Al11M, Al1J, Al2J, Al7J and Al11J are AF279914, AF282676, AF349553, AF349556, AF353170, AF349554, AF349555, AF353171, AF349557, AF353176, AF353178, AF353177, AF353172, AF353174, AF353175 and AF353173 respectively. Accession numbers for symbionts Sh2A, Sh6A, Sh8A, Sh4M, Sh5M, Sh6M, Sh7M, Sh5J, Sh6J, Sh9J and Sh10J are AF349552, AF349551, AF349550, AF349546, AF349547, AF349548, AF349549, AF349542, AF349543, AF349545 and AF349544 respectively.

Sequence and phylogenetic analyses. A search of GenBank using the derived sequences as search queries was conducted using FastA (Pearson \& Lipman 1988). Seventeen sequences from closely related symbiotic dinoflagellates were found (Table 2). These were used as reference sequences for subsequent alignments and analyses. Gymnodinium simplex was used as an outgroup (accession no. AF060901; Wilcox 1998).

Sequences were aligned using CLUSTAL W (Thompson et al. 1994). Trees were constructed using the neighbor-joining and maximum likelihood analyses options within the PHYLIP package (Felsenstein 1993). Distance matrices of pairwise divergence values were generated in PHYLIP using Kimura's 2-parameter model. Bootstrap analysis (1000 replicates for neighbor-joining and 100 replicates for maximum likelihood) was performed. The nodes were considered significantly robust if bootstrap values $>95 \%$ were obtained (Felsenstein 1985).

Data analysis. Analysis of molecular variance (AMOVA) was undertaken with the program Arlequin version 2.000 (Schneider et al. 2000) according to the procedure for DNA sequences. This procedure calculates standard variance components and an array of correlation measures or test statistics $\left(\phi_{\mathrm{ST}}\right)$. The test statistic $\phi_{\mathrm{ST}}$ is equivalent to Wright's $F_{\mathrm{ST}}$ (Wright 1951, Weir \& Cockerham 1984). The significance of observed variance components and $\phi$ statistics were tested using a random permutation procedure available in the Arlequin program. Symbionts were grouped according to host species and isolation region (namely, the Australian, Malaysian and Japanese groups). Pairwise distances using Kimura's 2-parameter model (measured by $\phi_{\mathrm{ST}}$ ) among host species and regions were calculated. Negative $\phi_{\mathrm{ST}}$ values were indicative of an

Table 2. Reference symbiotic dinoflagellate species and the accession numbers of their 28S rDNA sequences data stored in GenBank. Source 1: Trench \& Thinh (1995); 2: Wilcox (1998); 3: Baker et al. (1997); 4: Baker (1999)

\begin{tabular}{|c|c|c|c|c|c|}
\hline $\begin{array}{l}\text { Dinoflagellate species / } \\
\text { abbreviation }\end{array}$ & Host & $\begin{array}{l}\text { Location of } \\
\text { origin }\end{array}$ & $\begin{array}{l}\text { Accession } \\
\text { number }\end{array}$ & Clade & Source \\
\hline Gymnodinium linucheae/G. lin & Linucheae unguiculata & Caribbean & AF060893 & $\mathrm{A}$ & 1,2 \\
\hline Symbiodinium pilosum/S. pil & Zoanthus sociatus & Caribbean & AF060894 & A & 2 \\
\hline Symbiodinium sp./Sym1 & Cassiopea xamachana & Caribbean & AF060895 & $\mathrm{A}$ & 2 \\
\hline S.microadriaticum/S. mic & Cassiopea xamachana & Caribbean & AF060896 & $\mathrm{A}$ & 2 \\
\hline Symbiodinium sp./Sym2 & Tridacna gigas & IndoPacific & AF060897 & A & 2 \\
\hline Symbiodinium sp./Sym3 & Hippopus hippopus & IndoPacific & AF060898 & A & 2 \\
\hline Symbiodinium sp./Sym4 & Acropora cervicornis & Caribbean & U63480 & A & 3 \\
\hline S. bermudense/S. ber & Aiptasia tagetes & Caribbean & AF060891 & $\mathrm{B}$ & 2 \\
\hline S. pulchrorum/S. pul & Aiptasia pulchella & IndoPacific & AF060892 & $\mathrm{B}$ & 2 \\
\hline Symbiodinium sp./Sym5 & Aiptasis pallida & Caribbean & U63484 & $\mathrm{B}$ & 3 \\
\hline Symbiodinium sp./Sym6 & Agaricia fragilis & Caribbean & AF060889 & $\mathrm{C}$ & 2 \\
\hline Symbiodinium sp./Sym7 & Montastrea franksii & Caribbean & AF069890 & $\mathrm{C}$ & 2 \\
\hline Symbiodinium sp./Sym8 & Acropora cervicornis & Caribbean & U63481 & $\mathrm{C}$ & 3 \\
\hline Symbiodinium sp./Sym9 & Acropora cervicornis & Caribbean & U63482 & $\mathrm{C}$ & 3 \\
\hline Symbiodinium sp./Sym10 & Pavona duerdeni & IndoPacific & U63485 & $\mathrm{C}$ & 3 \\
\hline Symbiodinium sp./Sym11 & Pocillopora elegans & IndoPacific & AF170148 & $\mathrm{D}$ & 4 \\
\hline Symbiodinium sp./Sym12 & Pocillopora elegans & IndoPacific & AF170149 & $\mathrm{D}$ & 4 \\
\hline
\end{tabular}



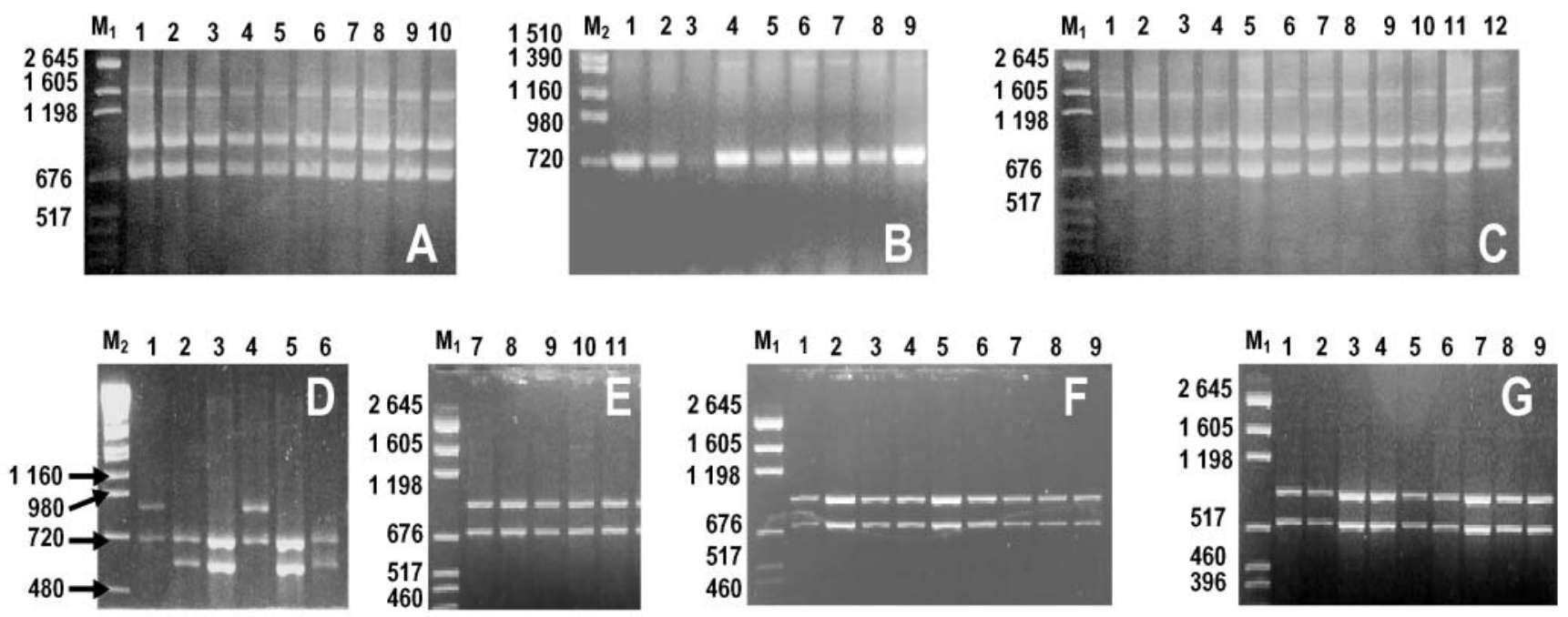

Fig. 1. Restriction fragment length polymorphism patterns derived from Taq 1 digestion of the amplified symbiotic dinoflagellate 18S rRNA gene. (A) Australian Seriatopora hystrix colonies; Lanes 1 to 10: Sh1A-Sh10A, respectively. (B) Malaysian S. hystrix colonies; Lanes 1 to 9: Sh1M-Sh9M, respectively. (C) Japanese S. hystrix colonies; Lanes 1 to 12: Sh1J-Sh12J, respectively. (D) \& (E) Australian Acropora longicyathus colonies; Lanes 1 to 11: Al26A, Al6A, Al13A, Al43A, Al45A, Al53A, Al1A, Al2A, Al3A, Al5A and Al23A, respectively. (F) Malaysian A. longicyathus colonies; Lanes 1 to 9: Al1M, Al2M, Al3M, Al4M, Al7M, Al8M, Al10M, Al11M and Al12M, respectively. (G) Japanese A. longicyathus colonies; Lanes 1 to 9: Al1J, Al2J, Al3J, Al4J, Al5J, Al6J, Al7J, Al8J and Al9J. Lanes $\mathrm{M}_{1}$ and $\mathrm{M}_{2}$ contain pGem DNA markers (Promega) and SPP1/Eco R1 DNA markers (Progen), respectively

absence of genetic structure among the populations compared (Schneider et al. 2000). p < 0.05 was considered significant.

\section{RESULTS}

PCR amplification of symbiotic dinoflagellate $18 \mathrm{~S}$ and 28S rRNA genes from all colonies produced amplicons of approximately 1500 and 600 bp, respectively. Taq 1 digestion of the amplified Seriatopora hystrix symbiont DNA produced 2 distinct RFLP patterns (Fig. $1 \mathrm{~A}$ to C). Symbionts from Australian and Japanese colonies produced an RFLP pattern typical for Clade $\mathrm{C}$ symbiotic dinoflagellates (Fig. 1 A, C, 2 discernible fragments, approximately $890 \mathrm{bp}$ and $700 \mathrm{bp}$ ) (Rowan \& Powers 1991a,b). Symbionts from Malaysian colonies produced a second RFLP pattern consisting of a single fragment of approximately $720 \mathrm{bp}$. Presumably, this consists of 2 equally sized fragments. This pattern was distinct from those previously described for Clades A, B or C, but resembled the pattern produced by the symbiont from Montipora patula from Hawaiian waters, which was not resolved into any clade (Rowan \& Powers 1991b).

Taq 1 digestion of the DNA amplified from 7 Australian, all Malaysian and all Japanese Acropora longicyathus symbionts produced an RFLP pattern typical for Clade C (Fig. 1D to G). However, amplicons of symbionts from the 4 remaining Australian colonies, Al6A,
Al13A, Al45A and Al53A, produced a distinct RFLP pattern (Fig. 1D, approximately 720 and $600 \mathrm{bp}$ ), which resembled that produced from Clade A symbiotic dinoflagellates (Rowan \& Powers 1991a,b)

\section{S rDNA D1/D2 sequence analysis}

We sequenced 400 to 550 nucleotides of the 28S D1/ D2 rDNA from 14 Seriatopora hystrix and 16 Acropora longicyathus colonies, representing each putative Clade and the unique RFLP pattern. The sequences derived from 1 or both strands of DNA were identical and unambiguous. Hence, sequencing of both strands was not undertaken for all amplicons and cloning was not required to separate potentially paralogous rDNA (Buckler et al. 1997) known to exist in Dinophyceae (Scholin \& Anderson 1996). A FastA search of Genbank using these sequences confirmed the clade identities suggested by the RFLP patterns. Furthermore, the FastA search with sequences from the Malaysian $S$. hystrix symbionts showed that they shared highest identity with Clade D symbionts (accession no. AF170148 and AF170149; Baker 1999). These sequences were aligned with each other and variable sites for each host species, clade and regional groupings were identified (Fig. 2).

Among Clade C symbionts there were 21 fixed differences observed between Australian and Japanese Seriatopora hystrix; 8 between Australian S. hystrix 

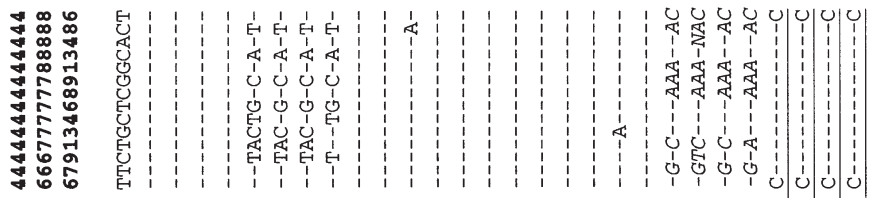

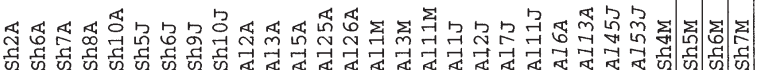
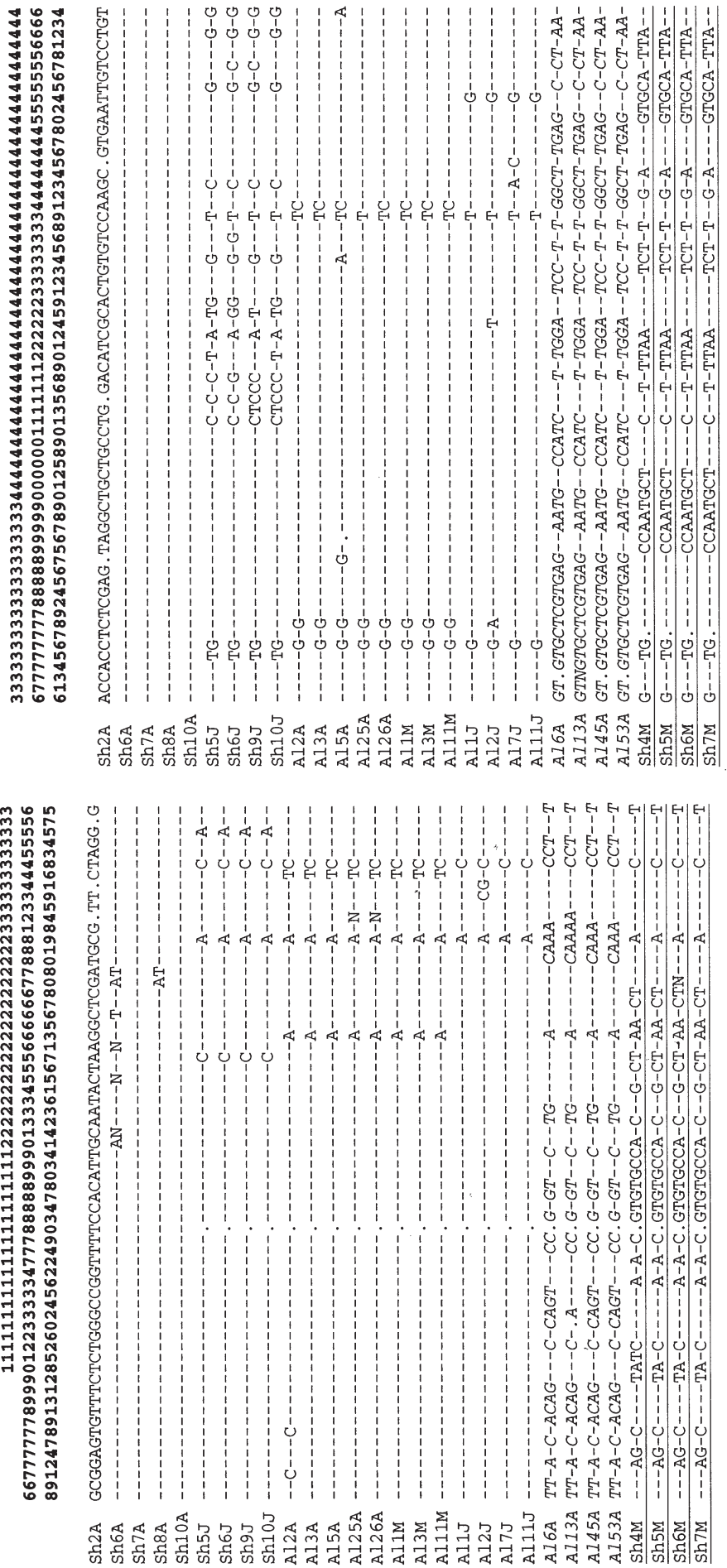

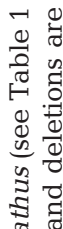

శี

넌 द्व

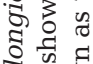

तี

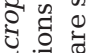

पृ:

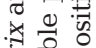

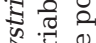

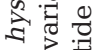

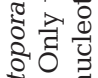

त्ष

क :

잉 :

ती

๑ั

ซृี ซี ซี

กิ

仓ิ

:

बृ

结要

젹 क्

थิ

운 항

I 0.

:ี

워 \&

का को

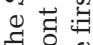

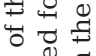

을 율

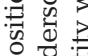

잌

응 뭄

줄 웅

궁

요을

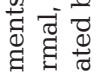

羊宅:

$\ddot{\theta} \dot{\theta}$

บิ

屯

ज़

ง $\frac{0}{2}$

宅 。ำ and Australian/Malaysian Acropora longicyathus, 6 between Australian S. hystrix and Japanese A. longicyathus, 19 between Japanese $S$. hystrix and Australian/Malaysian A. longicyathus, 12 between Japanese $S$. hystrix and Australian/ Malaysian A. longicyathus, none between Australian and Malaysian A. longicyathus, and 2 between Australian/Malaysian and Japanese A. longicyathus. Fortyeight fixed differences were observed between Clade A of Australian A. longicyathus and all the Clade C symbionts; 32 fixed differences were observed between Clade D symbionts and all Clade C symbionts; and 78 fixed differences observed between Clade A and Clade D symbionts.

The mean sequence identity among Clade C symbionts from Australian and Japanese Seriatopora hystrix; Australian, Malaysian and Japanese Acropora longicyathus, and a reference Clade $\mathrm{C}$ symbiont (U63485) was $96.5 \pm 0.4 \%$. Mean sequence identity among the Clade A Australian A. longicyathus symbionts and reference Clade A symbiont (accession no.U63480) was $98.3 \pm 0.4 \%$. The mean sequence identity among the Clade D Malaysian symbionts and the reference Clade D symbiont (AF170148) was $94.8 \pm$ $0.1 \%$.

\section{Phylogenetic analysis}

Neighbor-joining and maximum likelihood analysis of aligned 28S rDNA sequences produced trees that were congruent in topology. Only neighbor-joining trees are shown (Fig. 3). All of the Australian, Malaysian and Japanese symbionts from Seriatopora hystrix and Acropora longicyathus grouped with the appropriate reference clade symbionts.

Symbionts from Australian, Malaysian and Japanese Seriatopora hystrix formed distinct regional subgroups that were strongly supported by bootstrap analysis (Groups 1, 2 and 3, respectively. Fig. 3A). In contrast, all of the Clade $\mathrm{C}$ symbionts from Acropora longicyathus were genetically very similar to one another, regardless of region, and grouped in 1 strongly supported cluster (Group 4, Fig. 3B). Within this group, symbionts from Japan 


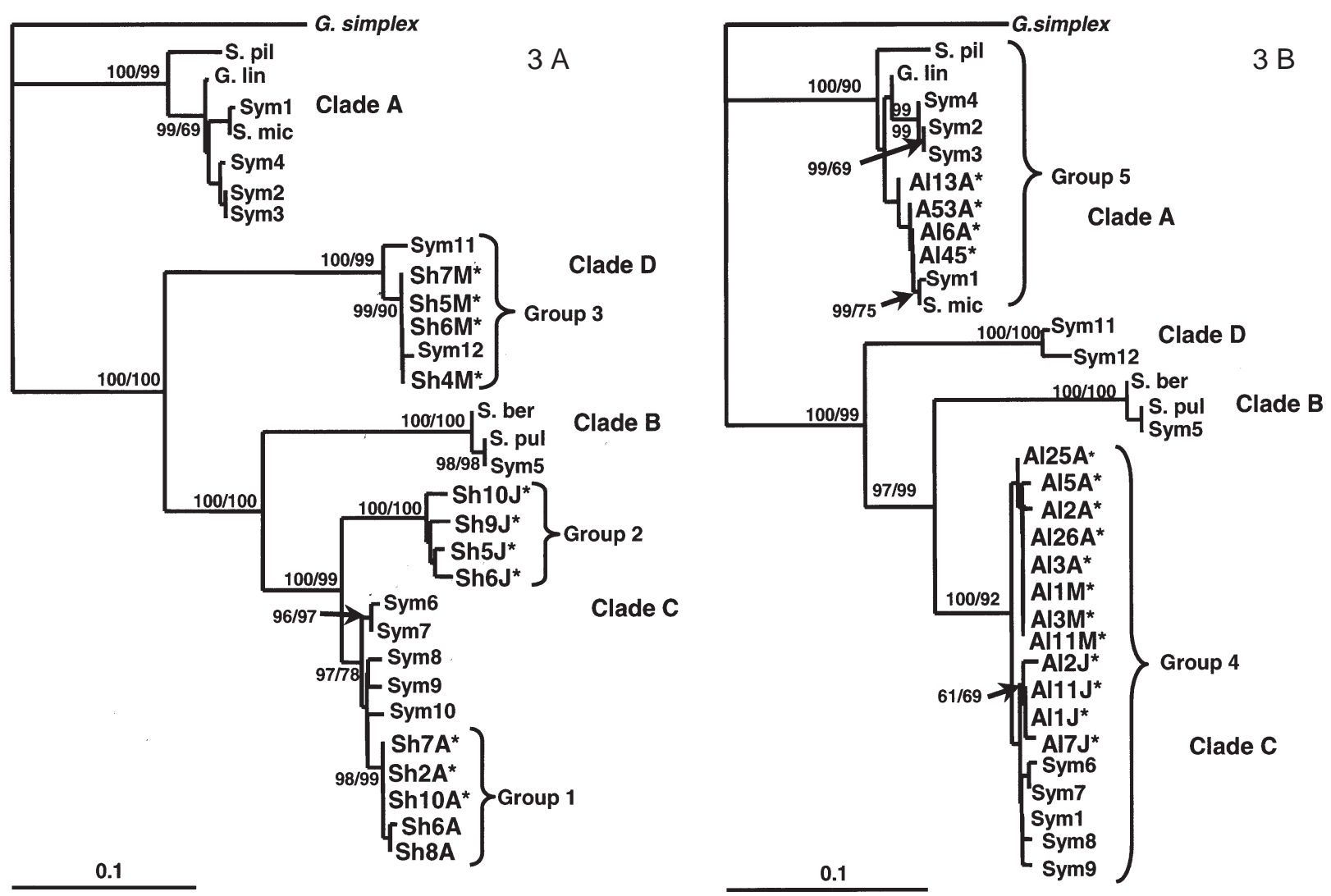

Fig. 3. Neighbor-joining trees derived from D1/D2 domains of the large subunit rRNA gene sequences of symbiotic dinoflagellates from (A) Seriatopora hystrix and (B) Acropora longicyathus, and other Symbiodinium spp. from several host species. *Symbionts from our study. Distances are number of substitutions per 100 bases. Unless indicated otherwise, only bootstrap values (neighborjoining/maximum likelihood) greater than $95 \%$ are shown at the nodes. The sequence of the outgroup free-living dinoflagellate Gymnodinium simplex was obtained from GenBank (accession no.AF060901; Wilcox 1998). See Table 2 for species abbreviations

Table 3. Analysis of molecular variance. Variance of Clade C symbionts among host species, regions and between individuals within populations. Regions are defined in text. *After 1023 random permutations

\begin{tabular}{|lcccr|}
\hline Source of variation & $\mathrm{df}$ & Sum of the squares & Variance component & $\%$ Total \\
\hline Among host coral species & 1 & 38.14 & 1.29 & 16.53 \\
Among regions & 3 & 69.89 & 5.43 & 0.190 \\
Among individuals within regions & 16 & 16.98 & 1.06 & 0.000 \\
Total & 20 & 125.01 & 7.78 & 13.64 \\
\end{tabular}

Table 4. Pairwise comparisons between populations of Clade C symbionts. Numbers are $\phi_{\mathrm{ST}}$ values performed through 10100 permutations. ${ }^{*} \mathrm{p}<0.05 ;{ }^{* *} \mathrm{p}<0.01$

\begin{tabular}{|llcccc|}
\hline & & 1 & 2 & 3 & 4 \\
\hline 1 & Australian Seriatopora hystrix Clade C & - & & & \\
2 & Japanese Seriatopora hystrix Clade C & $0.988^{* *}$ & - & & \\
3 & Australian Acropora longicyathus Clade C & $0.862^{* *}$ & $0.994^{* *}$ & - & - \\
4 & Malaysian Acropora longicyathus Clade C & $0.866^{*}$ & $1.000^{*}$ & -0.132 & $0.760^{* *}$ \\
5 & Japanese Acropora longicyathus Clade C & $0.7205^{* *}$ & $0.982^{*}$ & $0.756^{*}$ \\
\hline
\end{tabular}


formed a subgroup; however, the branch separating this group was not supported by bootstrap analysis (61\% and $69 \%$ for neighbor-joining and maximum likelihood analysis, respectively). Clade $\mathrm{C}$ symbionts of A. longicyathus from Australia and Malaysia could not be distinguished from each other. Clade A symbionts from A. longicyathus formed a closely related group (Group 5, Fig. 3B). When the phylogenetic relations among symbionts from both coral species were examined together, all 5 groups were maintained (Fig. 4).

\section{Analysis of molecular variance}

AMOVA was performed to evaluate the genetic differences between Clade $C$ symbionts among the 2 coral species, among Australian, Japanese and Malaysian regions, and within populations from these regions. The results are shown in Table 3. This analy-

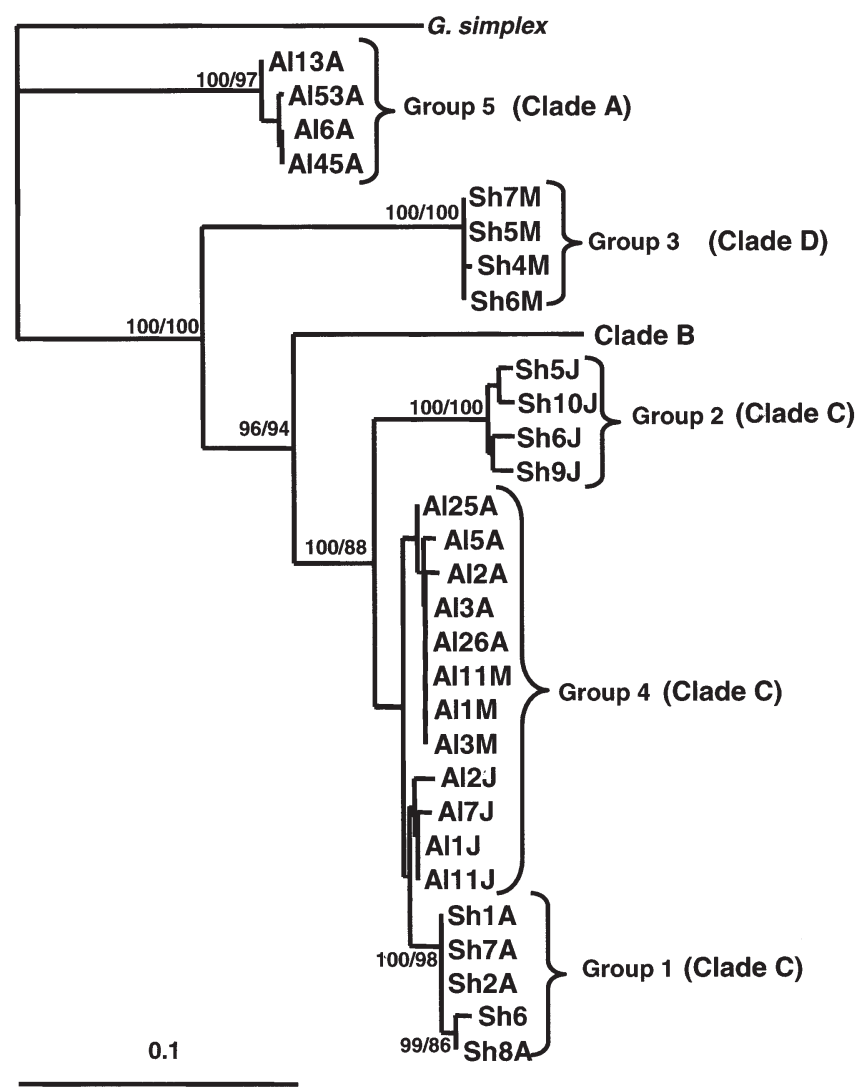

Fig. 4. Neighbor-joining tree derived from D1/D2 domains of the large subunit rRNA gene sequence alignments of symbiotic dinoflagellates from Seriatopora hystrix and Acropora longicyathus, with the free-living dinoflagellate Gymnodinium simplex as an outgroup. Distances are number of substitutions per 100 bases. Unless otherwise indicated, only bootstrap values (neighbor-joining/maximum likelihood) greater than $95 \%$ are shown sis was not performed on Clade A or D symbionts because they were found in 1 coral species and region only.

The greatest amount of variation was found among regional groups $(69.8 \%, \mathrm{p}<0.01)$. A lower but non-significant level of variation was found between the 2 coral host species $(16.5 \%, \mathrm{p}=0.19)$. Variation within populations was the lowest but was nevertheless significant $(13.6 \%, \mathrm{p}<0.01)$.

Pairwise comparisons between Clade $\mathrm{C}$ regional populations, measured by $\phi_{\mathrm{ST}}$ values, are shown in Table 4. Nine out of 10 pairwise comparisons showed significant differentiation ( $\mathrm{p}<0.05$ ). Only Australian and Malaysian Acropora longicyathus symbiont populations could not be differentiated ( $\mathrm{p}>0.05)$.

\section{DISCUSSION}

Despite the importance of questions concerning the biogeography of symbiotic dinoflagellates inhabiting invertebrates such as reef-building corals and clams, an understanding of this area is relatively undeveloped. This study has attempted to investigate the biogeography of symbiotic dinoflagellates at a large scale in the western Pacific. A major finding is that the identities of the symbionts from distantly located colonies can vary greatly despite being taken from the same host species. This phenomenon has also been observed in the coral species Plesiastrea versipora (Loh et al. 1998, Baker 1999, Rodriguez-Lanetty et al. 2001). The presence of these various Symbiodinium may reflect an adaptation to environments experienced at respective locations. Previously, Rowan et al. (1997) found evidence to suggest that some corals can adapt to changed environmental conditions by altering symbiont genotype composition and distribution along large coral colonies. Baker et al. (1997) showed that the symbiont genotype in colonies of Caribbean acroporids varied depending on depth.

However, the identical distribution of Clades A and $\mathrm{C}$ in adjacent colonies of Acropora longicyathus is difficult to explain. Why a coral species should have 2 different types of symbiotic dinoflagellates in colonies that are growing side by side is unresolved. This flexibility in partnership may represent undetected local scale differences or may simply be a result of serendipity and evolution of 2 separate but suitable physiological interactions.

\section{Symbiont diversity at broad scales}

All Clade C symbionts in our study consistently formed part of a larger group that also included sym- 
bionts of the corals Pavona duerdeni from Hawaii, and Acropora cervicornis, Agaricia fragilis and Montastrea franksii from the Caribbean. Similarly, all Clade A symbionts of our study formed part of a larger group that included symbionts of Indo-Pacific clams Hippopus hippopus and Tridacna gigas; Caribbean coral A. cervicornis; zoanthid A. tagetes; and the medussae Linucheae unguiculata and Cassiopea xamachana. Our Clade D Malaysian symbionts formed a group with symbionts of the eastern Pacific coral Pocillopora elegans from the reefs off Panama (Baker 1999). This pattern is consistent with the original observations of Rowan \& Powers (1991a,b), who used RFLP methods to distinguish 3 major clades of symbiotic dinoflagellates.

Examination of the variability of symbiotic dinoflagellates within individual coral species revealed some interesting properties. Clade C symbionts from Seriatopora hystrix growing at Australia and Japan were significantly different from each other and yet highly similar within each location. AMOVA, pairwise comparison of population differences and phylogenetic analyses of the rRNA sequence data supported these differences. This indicates that the Clade $\mathrm{C}$ symbionts of $S$. hystrix are genetically differentiated among their respective regions although further sampling needs to be done to confirm this.

Clade C symbionts from Acropora longicyathus were distinct from those of Seriatopora hystrix but similar to each other, regardless of their region of origin. Phylogenetic analyses of the rRNA sequence data could not resolve these symbionts into distinct regional groups; however, more sensitive analysis using pairwise comparisons found significant $\phi_{\mathrm{ST}}$ values between the Japanese symbionts and those from Australia and Malaysia. Nevertheless, these Australian and Malaysian Clade C symbionts appear to belong to a single group that is widespread in its distribution.

Since Clade A or D symbionts within our study were observed only in single locations, discussion of genetic connectivity (or lack of) is not possible for those groups.

\section{Host-symbiont lifecycle and symbiont diversity}

We hypothesize that genetically differentiated symbiont groups may be the result of events that led to periods of strong evolution of genetically isolated corals and symbionts. Conversely, genetically connected symbiont groups found over vast distances may result from the extent to which the holosymbionts or symbionts themselves are dispersed by ocean currents. In this case, some corals may propagate thousands of kilometers away from where the parent generation was located (Jokiel 1984, Richmond 1987, Jokiel 1990, Glynn et al. 1996). Symbionts may be propagated within drifting larvae or rafting corals, or may occur in a free-living phase and be acquired by hosts downstream. The mode of transmission of symbionts between host generations may also have a strong influence on the dispersal and extent to which symbiont and host are likely to co-evolve. The stronger intraspecies divergence between populations of symbiotic dinoflagellates of Seriatopora hystrix from Australia, Japan and Malaysia suggests that symbiont populations have been isolated-perhaps by the fact that vertical transmission occurs in this species.

These observations are supported by the biology of this coral species, particularly the short time it spends in its larval phase. The short-lived larval stage in turn drives an isolated and genetically divided distribution that is strongly restricted by oceanic circulation and reef structure (Ayre 1994, Ayre et al. 1997). The symbiosis between Seriatopora hystrix and its dinoflagellates, once established with a particular genotype, might never change over successive generations since vertical transmission ensures a faithful transmission of symbiont genotypes from parent to offspring generations (Yamamura 1996, Douglas 1998, Law \& Dieckmann 1998, Genkai-Kato \& Yamamura 1999). This has potentially led to the evolution of genetically divergent symbiont genotypes common to particular regions.

In the 'closed' system of Seriatopora hystrix, distantly separated coral populations have also adopted different symbionts. Interestingly, Clade D symbionts of Malaysian S. hystrix appear identical to those of Pocillopora elegans (Fig. 3A) from the Pacific reefs off Panama (Baker 1999). This suggests that symbiosis with this genotype was established early in ancestral forms and perhaps in multiple coral species and implies that sometime in evolutionary history, $S$. hystrix did not have such a closed system. It is less likely that the symbiont has changed so much in symbiosis with $S$. hystrix that it belongs in a different clade since it also forms a symbiosis with another species of coral.

In contrast, Acropora longicyathus acquires symbionts from the water column (horizontal transmission). The weaker intra-species divergence observed between populations of Clade $\mathrm{C}$ symbiotic dinoflagellates from this coral growing in Australia, Japan and Malaysia is likely to result from this 'open' mode of acquisition. Selecting symbionts from the water column each generation effectively 'dilutes' the extent to which these may differ, especially if the symbiont taxon is ubiquitous, and the evolution of a suitable physiological interaction between A. longicyathus and symbiont has ensured preferential uptake of the widespread zooxanthella genotype at all locations. Nevertheless, horizontally transmitted zooxanthellae may yet show patterns of geographic variation that mirror their dispersal in free-living form, which may explain 
the distinctiveness of Japanese A. longicyathus symbionts. The occurrence of Clades A or C in Australian colonies is perhaps a case in point. The hosts, occurring side by side, have adopted 2 very diverse symbionts that might provide respective physiological advantages. Although colonies of Seriatopora hystrix have also adopted diverse symbionts (either 1 of 2 Clade C or D genotypes), this variation is strongly linked with geographical separation.

To date, all species found to form symbioses with symbionts of more than 1 clade (Montastrea annularis and M. faveolata [Rowan \& Knowlton 1995, Rowan et al. 1997], Acropora cervicornis [Baker et al 1997], Diploria labyrinthiformis and Stephanocoenia michelinii [Baker \& Rowan 1997], Acropora longicyathus and Pavona decussata [Loh et al. 1998]) are species or belong to genera that have never been observed to release gametes or progeny equipped with symbiotic dinoflagellates (Harrison \& Wallace 1990, Richmond \& Hunter 1990), and hence probably have open symbioses.

These data show that the symbiotic dinoflagellates of widely distributed coral species are variable at the level of biogeographical regions. Acropora longicyathus symbionts appear to be genetically connected and widely distributed, perhaps because reinfection by the same zooxanthellae taxon occurs anew each generation. Seriatopora hystrix, perhaps because of an isolating effect of maternal transmission and limited larval distribution, have symbionts that are genetically differentiated according to geographic distribution. The different modes of symbiont transmission and resulting variation of symbionts within coral hosts may have major implications for evolution and versatility of dinoflagellate symbionts under the pressure of changing environmental conditions.

Acknowledgements. This study was supported by Australian Reseach Council funding to O.H.-G. and D.C. We thank Ms Misaki Takabayashi and Mr Affendi bin Yang Amri for their valued assistance on field trips. We are grateful for the help from the following people and organizations: Mr Mark Waugh and Ms Robyn Waugh, One Tree Island Field Station; Dr Ridzwuan bin Abdul Rahman, University of Sabah, Malaysia; Mr. Kamal Quadra, Maktab Perguruan Gaya, Kota Kinabalu, Malaysia; the park rangers of Taman Laut Pulau Redang, Periakanan, Malaysia; the staff at Pulau Gaya Station, Sabah Parks, Malaysia, the Malaysian Federal (Perikanan) and State (Sabah Parks) Government Authorities; Dr Michio Hidaka and his staff and students, University of The Ryukyus, Japan; the staff at Sesoko Island field station, Japan; and the staff at Akajima field station, Japan. Thanks to Ms Tien Bui for making nice gels and pictures.

\section{LITERATURE CITED}

Amann RI, Ludwig W, Schleiffer KH (1995) Phylogenetic identification and in situ detection of individual microbial cells without cultivation. Microbiol Rev 59:143-159
Arai T, Kato M, Heyward A, Ikeda A, Izuka T, Maruyama T (1993) Lipid composition of positively buoyant eggs of reef building corals. Coral Reefs 12:71-75

Atoda K (1951) The larva and post larval development of some reef building coral. IV. Seriatopora hystrix Dana. Sci Rep Tohoku Univ Fourth Ser (Biol) 19:33-39

Ayre DJ (1994) Evidence for restricted gene flow in the viviparous coral Seriatopora hystrix on Australia's Great Barrier Reef. Evolution 48:1183-1201

Ayre DJ, Hughes TP, Standish RJ (1997) Genetic differentiation, reproductive mode, and gene flow in the brooding coral Pocillopora damicornis along the Great Barrier Reef, Australia. Mar Ecol Prog Ser 159:175-187

Baker AC (1999) The symbiosis ecology of scleractinian corals. PhD dissertation, University of Miami

Baker AC, Rowan R (1997) Diversity of symbiotic dinoflagellates (zooxanthellae) in scleractinian corals of the Caribbean and eastern Pacific. Proc 8th Int Coral Reef Symp, Panama 2:1301-1306

Baker AC, Rowan R, Knowlton N (1997) Symbiosis ecology of two Caribbean acroporid corals. Proc 8th Int Coral Reef Symp, Panama 2:1295-1300

Benayahu Y, Schleyer MH (1998) Reproduction in Anthelia glauca (Octocorallia: Xeniidae): transmission of algal symbionts during planular brooding. Mar Biol 131:433-442

Blank RJ, Trench RK (1985) Speciation and symbiotic dinoflagellates. Science 229:656-658

Buckler ES, Ippolito A, Holtsford TP (1997) The evolution of ribosomal DNA: Divergent paralogues and phylogenetic implications. Genetics 145:821-832

Douglas AE (1998) Host benefit and the evolution of specialization in symbiosis. Heredity 81:599-603

Felsenstein J (1985) Confidence limits on phylogenies: An approach using the bootstrap. Evolution 39:783-791

Felsenstein J (1993) PHYLIP (Phylogeny Inference Package). Seattle: Department of Genetics, University of Washington

Genkai-Kato M, Yamamura N (1999) Evolution of mutualistic symbiosis without vertical transmission. Theor Popul Biol 55:309-323

Goreau TF, Goreau NI (1959) The physiology of skeleton formation in corals. II. Calcium deposition by hermatypic corals under various conditions in the reef. Biol Bull 117: 239-250

Glynn PW, Veron JEN, Wellington GM (1996) Clipperton Atoll (eastern Pacific): oceanography, geomorphology, reef-building coral ecology and biogeography. Coral Reefs 15:71-99

Harrison PL, Wallace CC (1990) Reproduction, dispersal and recruitment of scleractinian corals. In: Dubinsky Z (ed) Ecosystems of the world: coral reefs. Elsevier, Amsterdam, p 133-207

Hoegh-Guldberg O, Jones RJ (1999) Photoinhibition and photoprotection in symbiotic dinoflagellates from reefbuilding corals. Mar Ecol Prog Ser 183:73-86

Jokiel PL (1984) Long distance dispersal of reef corals by rafting. Coral Reefs 3:113-116

Jokiel PL (1990) Transport of reef corals into the Great Barrier Reef. Nature 347:665-667

Jones RJ, Hoegh-Guldberg O, Larkum AWD, Schreiber U (1998) Temperature-induced bleaching of corals begins with impairment of the $\mathrm{CO}_{2}$ fixation mechanism in zooxanthellae. Plant Cell Environ 21:1219-1230

Kojis BL (1986) Sexual reproduction in Acropora Isopora species Coelenterata Scleractinia I. Acropora cuneata and Acropora palifera on Heron Island Reef, Great Barrier Reef, Australia. Mar Biol 91:291-310

Law R, Dieckmann U (1998) Symbiosis through exploitation 
and the merger of lineages in evolution. Proc R Soc Lond Ser B Biol Sci 265:1245-1253

Loh WKW, Carter D, Hoegh-Guldberg O (1998) Diversity of zooxanthellae from scleractinian corals of One Tree Island (The Great Barrier Reef). In: Greenwood JG, Hall NJ (eds) Proceedings of the Australian Coral Reef Society, 75th Annual Conference, University of Queensland, Brisbane, p 141-150

Pearson WR, Lipman DL (1988) Improved tools for biological sequence comparison. Proc Natl Acad Sci USA 85: $2444-2448$

Richmond R (1981) Energetic considerations in the dispersal of Pocillopora damicornis (Linnaeus) planulae. Proc 4th Int Coral Reef Symp, Manila 2:53-156

Richmond RH (1987) Energetic competency of long-distance dispersal of planula larvae for the coral Pocillopora damicornis. Mar Biol 93:527-534

Richmond RH, Hunter CL (1990) Reproduction and recruitment of corals: comparisons among the Caribbean, the Tropical Pacific, and the Red Sea. Mar Ecol Prog Ser 60:185-203

Rodriguez-Lanetty M, Loh WKW, Carter D, Hoegh-Guldberg O (2001) Latitudinal variability in symbiont specificity within the widespread scleractinian coral Plesiastrea versipora. Mar Biol (in press)

Rosenthal A, Gautelle O, Craxton M (1993) Large-scale production of DNA sequencing templates by microtitre format PCR. Nucleic Acids Res 21:173-174

Rowan R, Knowlton N (1995) Intraspecific diversity and ecological zonation in coral-algal symbiosis. Proc Natl Acad Sci USA 92:2850-2853

Rowan R, Powers DA (1991a) Molecular genetic identification of symbiotic dinoflagellates (zooxanthellae). Mar Ecol Prog Ser 71:65-73

Rowan R, Powers, DA (1991b) A molecular genetic classification of zooxanthellae and the evolution of animal-algal symbioses. Science 251:1348-1351

Rowan R, Knowlton N, Baker AC, Jara J (1997) Landscape ecology of algal symbionts creates variation in episodes of coral bleaching. Nature 388:265-269

Schneider S, Roessli D, Excoffier L (2000) Arlequin ver. 2000: A software for population genetics data analysis. Genetics and Biometry Laboratory, University of Geneva, Geneva

Schoenberg DA, Trench RK (1980a) Genetic variation in Symbiodinium (=Gymnodinium) microadriaticum Freudenthal, and specificity in its symbiosis with marine invertebrates. I. Isoenzyme and soluble protein patterns of axenic cultures of Symbiodinium microadriaticum. Proc R Soc Lond Ser B Biol Sci 207:405-427

Schoenberg DA, Trench RK (1980b) Genetic variation in Symbiodinium (=Gymnodinium) microadriaticum Freudenthal, and specificity in its symbiosis with marine invertebrates. II. Morphological variation in Symbiodinium microadriaticum. Proc R Soc Lond Ser B Biol Sci 207:429-444

Schoenberg DA, Trench RK (1980c) Genetic variation in Symbiodinium (=Gymnodinium) microadriaticum Freudenthal, and specificity in its symbiosis with marine invertebrates. III. Specificity and infectivity of Symbiodinium microadriaticum. Proc R Soc Lond Ser B Biol Sci 207: $445-460$

Schwarz JA, Krupp DA, Weis VM (1999) Late larval development and onset of symbiosis in the scleractinian coral Fungia scutaria. Biol Bull 196:70-79

Scholin CA, Anderson DA (1996) Lsu rDNA-based RFLP assays for discriminating species and strains of Alexandrium (Dinophyceae). J Phycol 32:1022-1035
Seutin G, White BN, Boag PT (1991) Preservation of avian blood and tissue samples for DNA analyses. Can J Zool 69: $82-90$

Shlesinger Y, Goulet TL, Loya Y (1998) Reproductive patterns of scleractinian corals in the northern Red Sea. Mar Biol 132:691-701

Sier CJS, Olive PJW (1998) Reproduction and reproductive variability in the coral Pocillopora verrucosa. Mar Biol 118: $713-722$

Simkiss K (1964a) The inhibitory effects of some metabolites on the precipitation of calcium carbonate from artificial and natural seawater. J Cons Cons Perm Int Explor Mer 29:6-18

Simkiss K (1964b) Phosphates as crystal poisons of calcification. Biol Rev 44:487-505

Szmant FA, Yevich P, Pilson MEQ (1980) Gametogenesis and early development of the temperate coral Astrangia danae (Anthozoa: Scleractinia). Biol Bull 158:257-269

Thompson JD, Higgins DG, Gibson TJ (1994) CLUSTAL W: Improving the sensitivity of progressive multiple sequence alignment through sequence weighting, position-specific gap penalties and weight matrix choice. Nucleic Acids Res 22:4673-4680

Titlyanov EA, Titlyanova TV, Loya Y, Yamazato K (1998) Degradation and proliferation of zooxanthellae in planulae of the hermatypic coral Stylophora pistillata. Mar Biol 130:471-477

Trench RK (1979) The cell biology of plant-animal symbiosis. Annu Rev Plant Physiol 30:485-532

Trench RK (1997) Diversity of symbiotic dinoflagellates and the evolution of microalgal-invertebrate symbioses. Proc 8th Int Coral Reef Symp, Panama 2:1275-1286

Trench RK, Blank RJ (1987) Symbiodinium microadriaticum Fruendenthal, S. goreauii sp. nov., S. kawaguti sp. nov. and $S$. pilosum sp. nov.; Gymnodinoid dinoflagellate symbionts of marine invertebrates. J Phycol 23:469-481

Trench RK, Thinh LV (1995) Gymnodinium linucheae sp. nov.: The dinoflagellated symbiont of the jellyfish Linuche unguiculata. Eur J Phycol 30:149-154

Veron JEN, Pichon M (1976) Scleractinia of Eastern Australia. In: Australian Institute of Marine Science monograph series, Vol. 1. Australian Government Publishing Service, Townsville

Veron JEN, Wallace C (1984) Scleractinia of Eastern Australia. In: Australian Institute of Marine Science monograph series, Vol. 6. Australian National University Press, Townsville

Wallace CC (1985) Reproduction, recruitment and fragmentation in nine sympatric species of the coral genus Acropora. Mar Biol 8:217-233

Ward DM, Weller R, Bateson MM (1990) 16S rRNA sequences reveal numerous uncultured microorganisms in a natural community. Nature 345:63-65

Weir BS, Cockerham CC (1984) Estimating F-statistics for the analysis of population structure. Evolution 38:1358-1370

Wilcox T (1998) Large-subunit ribosomal RNA systematics of symbiotic dinoflagellates: morphology does not recapitulate phylogeny. Mol Phylogenet Evol 10:436-448

Wright S (1951) The genetical structure of populations. Ann Eugen 15:323-354

Yamamura N (1996) Evolution of mutualistic symbiosis: A differential equation model. Res Popul Ecol 38:211-218

Zardoya R, Costas E, Lopez-Rodas, V, Garrido-Pertierra A, Bautista JM (1995) Revised dinoflagellate phylogeny inferred from molecular analysis of large-subunit ribosomal RNA gene sequences. J Mol Evol 41:637-645

Submitted: ם; Accepted: March 15, 2001

Proofs received from author(s): October 16, 2001 